\title{
KOMPETENSI MULTIKULTURAL GURU PENDIDIKAN AGAMA ISLAM
}

\author{
Abdul Halim*, Maskuri** \\ Institut Pesantren KH Abdul Chalim \\ Email : abdulhalim44@gmail.com \\ Universitas Islam Malang \\ Email : maskuri@unisma.ac.id
}

\begin{abstract}
Abstrak
Indonesia sebagai negara majemuk dengan keberagaman budayanya memerlukan sosok guru yang mempunyai kompetensi multikultural dalam proses pendidikannya. Hal ini didasarkan pada pentingnya guru yang menyadari realitas kehidupan bangsa Indonesia. Terlebih lagi bagi guru Pendidikan Agama Islam yang menginternalisasikan nilai-nilai agama kepada peserta didik. Ia dituntut untuk dapat melaksanakan proses pembelajaran sesuai dengan realitas bangsa yang multikultur, oleh karena terkadang agama dijadikan alasan untuk abai terhadap keragaman budaya serta bersikap eksklusif kepada peserta didik. Kajian ini berupaya untuk mendeskripsikan dan menganalisis kompetensi multikultural guru PAI dan implementasinya dalam pembelajaran. Lokus kajian ini berada pada forum Musyawarah Guru Mata Pelajaran Pendidikan Agama Islam kabupaten Mojokerto. Penelitian ini menggunakan metode fenomenologi dengan arti bahwa bagaimana guru menyadari keberagaman yang ada dalam kehidupan terhadap relevansi kebutuhan kompetensi multikultural guru PAI. Hasil penelitian menyatakan pertama bahwa dalam konteks kehidupan multikultural dan keragaman peserta didik, guru PAI dituntut untuk mempunyai kompetensi keilmuan, multikultural, profesional, sosial dan leadership. Kedua, ruang lingkup kompetensi multikultural dapat diklasifikasikan pada aspek sikap positif, basis pemahaman multikultural, skill pedagogi dan kompetensi leadership guru PAI
\end{abstract}

Kata Kunci: Kompetensi Multikultural, Guru PAI

\section{Abstract}

As a pluralistic country, Indonesia with its cultural diversity requires a teacher having multicultural competence in the educational process. Based on the importance of teachers who are aware of the realities of Indonesian life. Especially for Islamic Religious Education teachers who internalize religious values to students. The Required teacher can carry out the learning process appropriate towards the reality of a multicultural nation because occasionally belief in religion was taken as an excuse to ignore cultural diversity and having exclusive on facing students. This study aims 
to describe and analyze the multicultural competence of Islam Education teachers and its scope. The study focused on the Forum on Islam Education Subject Teacher for junior high school in Mojokerto regency. The research uses the phenomenological method, it means teacher awareness of diversity, needs multicultural competence. The research states, first, in the context of multicultural life and diversity of students, craved Islam education teachers who have a knowledge base, multicultural, professional, social, and leadership competencies. Second, the scope of multicultural competence can be classified into aspects; positive attitudes, the basis of multicultural understanding, pedagogical skills, and leadership competency.

Keywords: Multicultural Competence, Islamic Education Teacher

\section{PENDAHULUAN}

Berbicara mengenai pendidikan agama Islam di sekolah, perlu dipahami bahwa pengembangan pendidikan agama Islam berpotensi untuk menjadikan persatuan dan kesatuan (integrasi) atau disintegrasi (perpecahan) dalam masyarakat. Persoalan ini perlu diantisipasi dan disadari dengan baik oleh guru Pendidikan Agama Islam. Artinya bahwa ketika guru agama Islam mempunyai pandangan yang positif pada peserta didik dan mengarahkannya dengan baik, maka berdampak positif pula bagi peserta didik atau sebaliknya. Hal ini ditegaskan oleh ketua MGMP PAI Mojokerto bahwa ketika tafsir terhadap agama itu tidak tepat maka akan juga berdampak pada subyek guru tersebut dalam berperilaku. ${ }^{1}$ Dalam konteks kehidupan bangsa Indonesia yang multikultural, guru PAI dituntut untuk mempunyai kompetensi multikultural dan mengimplementasikannya dalam pembelajaran. Sehingga kemajemukan dan keragaman budaya bangsa dapat disikapi secara positif oleh guru PAI. Sikap positif tersebut diharapkan dapat mengarahkan pendidikan bangsa Indonesia ke arah yang lebih baik.

Guru adalah salah satu komponen yang penting dalam pendidikan. Unsur guru sebagai instrumen manusiawi yang ada dalam pendidikan berperan untuk pembentukan karakter dan internalisasi nilai-nilai yang diharapkan oleh pelaku pendidikan. Begitu pentingnya kedudukan guru dalam pendidikan, keberhasilan transfer of value tidak dapat dilepaskan dari peranannya. Oleh karena itu, sebagaimana amanat Undang-undang tentang guru no 14 tahun 2005 disebutkan pada pasal 10 bahwa guru diwajibkan mempunyai kompetensi yang meliputi kompetensi pedagogik, kompetensi kepribadian, kompetensi sosial, dan kompetensi profesional yang diperoleh

\footnotetext{
${ }^{1}$ Aan Eko Ubaidillah. Wawancara (Mojokerto 24 Oktober 2017)
} 
melalui pendidikan profesi. ${ }^{2}$ Kewajiban guru untuk mempunyai kompetensi sebagaimana disebut di atas adalah hal yang lumrah mengingat keberadaannya sebagai agent of change dalam membentuk karakter dan kebudayaan bangsa. Terlebih lagi berkaitan dengan kompetensi sosial yang menempatkan pendidik sebagai bagian dari masyarakat untuk berkomunikasi dan bergaul secara efektif dengan seluruh elemen-elemen yang ada dalam pendidikan.

Kompetensi multikultural seperti kesadaran akan keberagaman peserta didik, budaya, tradisi dan nilai-nilai kebudayaan yang dianut, serta keterlibatan diri dalam pengembangan multikultural di sekolah merupakan hal penting bagi guru. Berkaitan dengan penelitian ini ditemukan hal-hal yang tampak di permukaan guru-guru yang termasuk dalam forum Musyawarah Guru Mata Pelajaran PAI Kab Mojokerto dalam kategori masih baik dalam hal kompetensi multikultural. ${ }^{3}$

Dalam konteks pendidikan saat ini, kompetensi tersebut harus selalu dikembangkan mengingat Indonesia sebagai negara multikultur membutuhkan sosok seorang guru agama Islam yang sesuai dengan konteks kehidupan masyarakat Indonesia yang multikultur. Kajian ini mencoba untuk mendeskripsikan dan menganalisis kompetensi multikultural guru PAI dan impelementasinya dalam pembelajaran. Sejalan dengan amanat undang-undang yang memberikan amanah pada guru untuk berusaha menjadikan peserta didik sesuai dengan tujuan pendidikan nasional yaitu mencetak suatu generasi cerdas, beriman, bertakwa, berilmu, cakap, kreatif, mandiri dan menjadi warga negara yang demokratis dan bertanggung jawab. $^{4}$

\section{METODE PENELITIAN}

Penelitian ini berparadigma post positivistik di mana model pendekatan yang digunakan adalah model olah kata Verbal dalam membuat keputusan. ${ }^{5}$ Sedangkan jika ditinjau dari pendekatan, penelitian ini menggunakan pendekatan kualitatif. Pendekatan tersebut pada umumnya bermakna bahwa data penelitian yang dikumpulkan lebih berbentuk katakata, dan cenderung bersifat deskriptif. Harapannya penelitian ini dapat mendeskripsikan dan menganalisis fenomena kesadaran guru pendidikan

${ }^{2}$ http://sumberdaya.ristekdikti.go.id/wp-content/uploads/2016/02/uu-

nomor-14-tahun-2005-ttg-guru-dan-dosen.pdf diakses tanggal 29 Nopember 2017

${ }^{3}$ Aan Eko Ubaidillah. Wawancara (Mojokerto 24 Oktober 2017)

4 Undang-undang nomor 20 Tahun 2003 tentang Sistem

Pendidikan Nasional (Jakarta: Visimedia, 2007) hlm 5

${ }^{5}$ Conny R Setiawan, Metode Penelitian Kualitatif: Jenis, Karakteristik dan Keunggulannya (Jakarta: Grasindo, 2010) hlm 46 
agama Islam di Mojokerto terhadap realitas keberagaman yang dihubungkan dengan kebutuhan kompetensi multikultural serta implementasinya dalam pembelajaran.

Secara umum, pengambilan data penelitian menggunakan teknik wawancara mendalam terhadap subjek penelitian dan informan. Subjek penelitian dalam penelitian ini adalah guru Pendidikan Agama Islam kabupaten Mojokerto yang tergabung dalam forum Musyawarah Guru Mata Pelajaran Pendidikan Agama Islam. Observasi dilaksanakan secara langsung, di mana peneliti terjun ke lapangan untuk mengamati dan memahami konteks kehidupan guru dan pembelajaran PAI di sekolah. Selanjutnya teknik pengumpulan data tersebut disempurnakan dengan mengumpulkan dokumen-dokumen terkait seperti kegiatan pembelajaran serta kegiatan lain yang relevan dengan data-data penelitian.

Tahapan dalam menganalisis data penelitian dimulai dengan display data, reduksi data, coding data. Pada tahapan ini peneliti menggunakan software NVivo sebagai tools penelitian kualitatif. Tujuannya agar data penelitian tidak tercecer dan tersimpan rapi sehingga analisis data dapat berjalan secara maksimal. Adapun analisis data yang digunakan dalam penelitian sesuai dengan praktik analisis data fenomenologi. Sebagai metode analisis dalam menafsirkan dan menganalisis data fenomenologi, peneliti melakukan tahapan-tahapan analisis seperti, reading-rereading, initial noting, eksplotari, searching for connection a cross emergent themes. Keempat tahapan tersebut diulang-ulang pada data penelitian yang ada dan selanjutnya hasil dari analisis data tersebut diakhiri dengan looking for patterns accross cases ${ }^{6}$

\section{PEMBAHASAN}

\section{Kajian Teoretis Kompetensi Multikultural Guru}

Secara fungsional guru sebagai orang yang mempunyai peran menyampaikan materi dan bertugas dalam menginternalisasikan nilai-nilai serta kompetensi yang dikehendaki sebagaimana termaktub dalam rumusan pendidikan. Fungsinya sebagai tenaga pendidik mengisyaratkan dirinya adalah pejuang akademik. ${ }^{7}$ Namun yang dipahami bahwa tugas guru bukanlah hanya mengajar saja, lebih dari itu bahwa guru adalah aktor di balik kesuksesan dalam pendidikan. kualitas pendidikan juga tergantung pada kompetensi dan kualitas guru-gurunya.

${ }^{6}$ Jonathan A Smith, Interpretative Phenomenological Analysis: Theory, Methode and Research, (Los Angeles; Sage, 2009) hlm 79-107

${ }^{7}$ Mulyana A Z, Rahasia Menjadi Guru Hebat (Jakarta: Grasindo, 2010) $\mathrm{hlm} 4$ 
Hal ini didasarkan pada hasil suatu penelitian yang menginvestigasi pendidikan di Indonesia dengan tema "Educating Indonesia". Pada laporannya, penelitian tersebut berusaha untuk menjawab pertanyaan penelitian yaitu mengapa pendidikan di Indonesia menempati salah satu peringkat terburuk di dunia. Ternyata laporan tersebut menyatakan bahwa hanya $51 \%$ pendidik di Indonesia yang memenuhi standard kompetensi untuk dapat mengajar dengan baik dan profesional ${ }^{8}$

Oleh karena itu seharusnya guru mempunyai kompetensi sebagai prasyarat dalam mencapai kesuksesan pendidikan. Pertama: kompetensi pedagogik. Kompetensi pedagogik adalah kemampuan guru untuk melaksanakan sesuatu yang didapatkan dari pendidikan. pengartian ini mengisyaratkan bahwa sikap guru harus bersifat rasional dan sistematis. Indikator seorang pendidik telah mempunyai kompetensi pedagogik meliputi kemampuan mengenal peserta didik baik secara psikologis maupun teknik penerapan pembelajaran pada peserta didik. Selain itu kompetensi pedagogik menuntut pendidik untuk mempunyai kemampuan dalam merencanakan, pengelolaan kelas dan kemampuan untuk pengorganisasian pembelajaran.

Kedua: kompetensi profesional diartikan dengan kemampuan guru dalam bidang penguasaan materi yang diajarkan. ${ }^{9}$ Dengan harapan agar peserta didik mencapai standar ketuntasan belajar dengan optimal. semakin luas dan dalam penguasaan materi guru akan berimbas pada pemahaman dan penguasaan materi peserta didik secara baik dan komprehensif. Ketika guru tidak mempunyai profesionalitas yang memadai, standard kelulusan peserta didik akan menjadi tidak ideal atau bahkan kurang dari standard.

Ketiga: kompetensi kepribadian mencerminkan kemampuan guru untuk menjadi pribadi yang dapat dijadikan sebagai role model oleh peserta didik. Kemampuan ini mengharuskan guru dapat mengendalikan dirinya dan memberikan teladan baik kepada peserta didik. Sehingga dengan ini peserta didik tidak kebingungan mencari contoh nyata hal-hal yang baik dalam proses belajarnya. Utamanya berkaitan dengan nilai-nilai, guru harus berada pada garda terdepan dalam melaksanakannya. Secara terperinci indikator seorang guru telah mempunyai kompetensi kepribadian ditandai dengan cerminan seorang guru yang kepribadiannya mantap, stabil, dewasa, arif dan berwibawa, menjadi teladan bagi peserta didik dan berakhlak mulia. ${ }^{10}$

${ }^{8}$ Muhaimin, Model Pengembangan Kurikulum dan Pembelajaran dalam Pendidikan Islam Kontemporer (Malang: UIN Maliki Press, 2016) hlm 49

${ }^{9}$ Tim Pengembang Ilmu Pendidikan UPI, Ilmu dan Aplikasi Pendidikan bag 4 (Jakarta: Grasindo, 2007) hlm 404

${ }^{10}$ Syamsul Bachri Thalib, Psikologi Pendidikan Berbasis Analisis Empiris Aplikatif(Jakarta: Prenada Media,2017) hlm 274 
Dalam konteks multikulturalisme kompetensi kepribadian ini mengarahkan kepada guru untuk menjadi pribadi yang patut diteladani sebagai sosok yang terbuka, inklusif, toleran, menghargai perbedaan dan menempatkan martabat manusia sesuai dengan kedudukannya. Pribadipribadi arif, bijaksana patut untuk ditampilkan oleh seorang guru pada peserta didik dalam menyemai nilai-nilai multikultural.

Kompetensi sosial: adalah kemampuan guru dalam kesehariannya untuk bersikap inklusif, tidak bersikap diskriminatif terhadap peserta didik, mampu berbicara secara empatik, efektif dan santun kepada peserta didik, rekan sejawat, orang tua dan masyarakat. ${ }^{11}$ Kompetensi sosial guru meletakkan guru sebagai bagian dari masyarakat. Idealnya sebagai bagian masyarakat guru harus taat pada aturan sosial.

Jika dikaitkan dengan penelitian ini yang mencoba untuk mengungkap kompetensi multikultural guru PAI sebagai respons dari keragaman etnis, agama maupun budaya dengan konsep kesetaraan, maka pandangan tentang kompetensi sosial ini perlu untuk dielaborasi menjadi suatu pemahaman kompetensi guru yang multikultural. Berkaitan dengan itu, indikator seorang guru mempunyai kompetensi sosial yang tinggi ditandai dengan sifat-sifat seperti, tidak mengkritik, menghakimi, atau mengeluh, memberi penghargaan yang jujur dan tulus, menunjukkan minat dan ketertarikan yang tulus terhadap orang lain, tersenyum dan berlapang dada; membuat orang lain merasa penting dan berharga; mengajukan pertanyaan. Tidak memberikan perintah langsung, bersikap terbuka terhadap pendapat dan kritis, menunjukkan empati kepada orang lain; menghargai keragaman dan perbedaan peserta didik, guru dan masyarakat, berempati dan suka menolong.12

Selain itu, yang perlu dikembangkan berkaitan dengan kompetensi guru multikultural adalah bahwa seorang guru PAI dalam pembelajarannya mencoba mengkomunikasikan materinya sesuai dengan konteks keragaman peserta didik. Dengan harapan pertama guru dapat mendiskusikan sumbangan aneka budaya dan orang dari suku lain dalam hidup bersama. Kedua guru juga berupaya untuk mendiskusikan bahwa semua orang dari budaya apa pun ternyata juga menggunakan hasil kerja orang lain dari budaya lain. ${ }^{13}$ Untuk mencapai kepada hal tersebut perlu usaha yang

11 Rofaah, Pentingnya Kompetensi Guru dalam Kegiatan Pembelajaran Perspektif Islam (Yogyakarta: Depublish, 2017) hlm 74

12 Raihani, Pendidikan Islam dalam Masyarakat Multikultural (Yogyakarta: Pustaka Pelajar, 2016) hlm 102

${ }^{13}$ Kasinyo Harto, Model Pengembangan Pedidikan Agama Islam (Jakarta: Raja Grafindo, 2014) hlm 97 
sistematis dan terstruktur dengan baik untuk dapat menjadikan guru-guru di Indonesia yang berwawasan multikulturalisme.

Secara umum kompetensi guru multikultural mensyaratkan adanya pertama sikap positif terhadap keanekaragaman budaya serta memahami pentingnya gerakan reformasi sekolah terhadap budaya multikultural dan memiliki keinginan untuk meningkatkan wawasan global dan multikultural dalam tindakannya. Kedua adalah basis pemahaman multikultural guru. Guru diharapkan mampu memahami persoalan etnis, nasional dan nilai-nilai global; keragaman dan budaya; preference dan belajar peserta didik yang berbeda disebabkan oleh budaya, agama dan lingkungannya; tradisi pedagogis masyarakat dari berbagai macam kelompok budaya yang tergambar di dalam kelas, sekolah dan masyarakat. Ketiga: basis skill pedagogi seorang guru. Dalam mengembangkan nilai-nilai multikultural seorang pendidik harus mempunyai skill pedagogi yang cukup seperti bagaimana meningkatkan kapasitas peserta didik dalam memiliki nilai-nilai lokal dan global; mengajarkan murid-murid untuk menjadi toleran dan menghargai perbedaan. ${ }^{14}$ Pernyataan tersebut menunjukkan bahwa untuk menjadi guru multikultural setidaknya memerlukan perspektif multikulturalisme yang baik dan kemampuan skill pedagogi guru dalam mengembangkan dan menyampaikan nilai-nilai multikulturalnya. Pemahaman guru yang baik tentang multikulturalisme akan berimplikasi terhadap tindakan nyata seorang pendidik dan komitmennya untuk mengembangkan multikulturalisme kepada peserta didik.

\section{Kompetensi Multikultural Guru Pendidikan Agama Islam}

Secara umum penilaian tentang kompetensi multikultural guru Pendidikan Agama Islam Kabupaten Mojokerto, dapat dikatakan cukup baik. Penilaian ini diungkapkan oleh pengawas guru-guru PAI SMP, SMA dan SMK Kabupaten Mojokerto. Ia menilai bahwa wawasan keberagaman budaya guru PAI selama ini tidak menemui kendala. Sangat wajar jika guruguru PAI SMP Kabupaten Mojokerto mempunyai wawasan dan sikap multikultural. Mengingat keberadaan mereka sebagai guru PAI bertugas pada sekolah umum. Sekolah di mana guru, peserta didik maupun lingkungannya cenderung beragam dan multikultural. Secara alamiah, mereka guru-guru PAI akan terbiasa dan belajar tentang nilai-nilai multikultural, oleh sebab faktor keragaman peserta didik yang menuntut

14 Ilghiz M Sinagatullin, Constructing Multicultural Education in a Diversity Society (USA: Scarecrow Press, 2003) hlm 237 
dirinya untuk belajar dan bersikap multikulturalis. ${ }^{15}$ Di lain pihak, mereka juga dituntut untuk menanamkan nilai-nilai dasar pada peserta didiknya. Termasuk dalam nilai-nilai multikultural. Berkaitan dengan pernyataan di atas, temuan penelitian tentang kompetensi multikultural guru PAI adalah sebagai berikut:

1. Kompetensi keilmuan.

Kompetensi yang dimaksud adalah kemampuan guru dan penguasaan guru tentang ilmu-ilmu yang dikaitkan dengan guru. Seorang guru diharapkan mempunya basis pemahaman yang kuat. Sehingga sikap yang keluar dari seorang guru mencerminkan keilmuannya. Dalam konteks multikultural guru diharapkan mempunyai basis pemahaman multikulturalisme yang memadai. Sebab, dengan penguasaan ilmu dan basis pemahaman multikultural tersebut, guru tidak menjadi eksklusif dan tidak gampang klaim sepihak dan merasa benar sendiri. ${ }^{16}$ Basis pemahaman tentang keragaman budaya menjadi kebutuhan bagi guru dalam menghadapi murid yang berlatar belakang kebudayaan berbeda. Oleh karena pemahaman tentang multikulturalisme membantu seorang guru memahami hakikat kebudayaan tidak akan pernah mencapai derajat monokultur. Dengan dasar dan kesadaran guru tentang multikulturalisme ini, akan menjadikan guru lebih terbuka dan menerima fakta multikultural dalam kehidupannya.

Temuan penelitian sebagaimana diungkap di atas mempunyai arti bahwa penerimaan guru terhadap keberagaman ditentukan oleh penguasaan basis pengetahuan multikultural. Seorang pendidik diharapkan terus belajar dan memperluas cakrawala keberagaman budaya. Demikian itu, tidak lain sebagai penunjang agar guru dapat menampilkan model seorang pengajar multikulturalis. Sensitivitas kebudayaan ini tidak mungkin dimiliki oleh guru tanpa adanya penguasaan dan kemampuan guru dalam membaca keragaman budaya. Oleh karenanya, kompetensi terhadap basis pemahaman multikultural guru mutlak dibutuhkan bagi seorang guru sebagai bekal mengajar. Terlebih lagi guru menghadapi siswa yang beragam kebudayaan. ${ }^{17}$

Fakta tentang kompetensi pemahaman guru terhadap keragaman budaya sebagai bagian dari kemampuan guru PAI dalam konteks multikultural diartikan oleh pendidik guru PAI dengan pemahaman tentang ragam budaya dan kebudayaan itu sendiri. Pemahaman terhadap ragam budaya dapat mengarahkan guru menjadi seorang yang tidak mudah marah, menghormati dan menghargai perbedaan. Sesungguhnya kompetensi

15 Observasi SMP Negeri kabupaten Mojokerto tanggal 19 Maret 08Agustus 2019

${ }^{16}$ Sodiqin, Wawancara (Mojokerto 1 Mei 2019)

${ }^{17}$ Nanang Nur Wakhid, Wawancara (Mojokerto, 19 Juni 2019) 
pengetahuan multikultural ini tidak lain adalah bagian dari pengembangan kesadaran diri guru dalam memaknai realitas siswa atau anak didik yang mempunyai keragaman secara kultural. ${ }^{18}$ Dengan demikian, apa yang tersampaikan dari guru mengenai kompetensi pemahaman dan keilmuan guru tentang multikultural sebagai kompetensi multikultural guru PAI, berpijak dan didasarkan pada urgensi kebutuhan guru Pendidikan Agama Islam dalam menghadapi keberagaman.

Selanjutnya, guru Pendidikan Agama Islam menambahkan tentang pentingnya basis keilmuan Islam sebagai bagian dari kompetensi keilmuan guru. Pemahaman keilmuan Islam dimaksud adalah pemahaman guru terhadap kajian Islam secara mendalam, detail dan komprehensif. Pemahaman Islam guru PAI diharapkan bersifat utuh dan tidak terpotong. Dengan ini, seorang guru tidak mudah dikaburkan oleh pemahaman yang bersifat konfrontatif dan melihat perbedaan serta keragaman budaya dengan kacamata sempit. ${ }^{19}$ Pernyataan di atas bersifat antisipatif terhadap keberadaan guru agar tidak terjebak pada pemahaman agama yang parsial, sehingga pemahaman ajaran Islam yang tidak utuh ini dikhawatirkan dapat menyebabkan seorang guru terjebak pada eksklusivisme beragama.

Sependapat dengan apa yang disebutkan di atas, terungkap akan pentingnya guru tidak berkutat pada paham yang dangkal. Hal ini didasarkan pada realitas gerakan radikalisme di mana faktor gerakan radikal ternyata masih berhubungan dengan dangkalnya pemikiran seseorang terhadap ajaran Islam. Oleh karenanya faktor kompetensi keilmuan seorang guru perlu ditingkatkan dan dikembangkan. Utamanya yang berkaitan dengan pemahaman multikultural dan ajaran Islam yang ramah. Tujuannya adalah untuk menutup pintu eksklusivisme bagi seorang pendidik. ${ }^{20}$

2. Kompetensi Multikultural.

Kompetensi tersebut bermakna bahwa Pengajar PAI diharapkan mampu bersikap multikulturalis pada setiap anak didik. Guru diharapkan memberikan contoh keteladanan berupa sikap multikultural yang dipraktikkan dalam lingkungan sekolah. Guru dianjurkan untuk berperilaku multikultural seperti menghormati, menghargai, bersikap ramah dan tidak diskriminatif kepada peserta didik. Dapat dicontohkan dalam hal ini seperti sikap guru tidak mengeksklusifkan diri dengan menjadikan tempat duduk muslim dengan muslim atau non-muslim dengan peserta didik yang mempunyai keyakinan yang sama. ${ }^{21}$

${ }^{18}$ Aan Eko Ubaidillah. Wawancara (Mojokerto 19 Maret 2019)

${ }^{19}$ Khoirul Anam, Wawancara (Mojokerto 13 Juni 2019)

${ }^{20}$ Nasruddin Hilmi, Wawancara (Mojokerto 04 Maret 2019)

${ }^{21}$ Abdul Rohman, Wawancara (Mojokerto 08 April 2019) 
Di antara kompetensi multikultural sebagaimana disebut di atas adalah kepekaan seorang guru terhadap anak didiknya seperti berusaha semaksimal mungkin dalam menjelaskan perbedaan tidak menyinggung perasaan dan pemahaman pihak lain. Lebih lanjut arti kompetensi multikultural dalam pandangan guru PAI adalah sikap di mana seorang guru mudah menerima masukan tidak memaksakan diri serta tidak menutup diri dari kebenaran yang datang dari mana pun asalnya. ${ }^{22}$

3. Kompetensi profesional.

Kompetensi ini adalah kemampuan guru memahami profesinya dalam mengaplikasikan nilai-nilai multikultural. Kesadaran guru terhadap profesinya menjadikannya mampu melihat realitas keberagaman dari peserta didik. Kemampuan guru dalam memahami profesinya tersebut disandingkan dengan kesadaran tentang norma-norma yang mengikat seorang guru untuk bersikap multikultural terhadap peserta didik. ${ }^{23}$ Ketika seorang guru mampu menyadari profesinya sebagai jabatan yang mengharuskan pendidik bersikap multikultural, maka kemampuan tersebut akan menjadikannya sebagai guru multikultural.

4. Kompetensi sosial.

Kompetensi sosial adalah kemampuan guru berinteraksi dalam pergaulan masyarakat dengan baik. Kemampuan tersebut diukur dengan sejauh mana seorang guru menempatkan dirinya di tengah-tengah masyarakat. Di antara contoh yang dapat ditamsilkan bagaimana sikap guru terhadap siswa yang berbeda kebudayaan. Ia dituntut untuk menampilkan wajah pendidik yang ramah, empatik serta penuh kasih sayang terhadap siswa dari berbagai latar kebudayaan dan preference berbeda. Sebagai seorang guru, ia diharapkan dapat menampilkan kompetensi sosialnya dengan gambaran guru yang humble, bersahaja dan terbuka terhadap perbedaan. ${ }^{24}$ Sikap sosial yang ramah, hangat serta penuh keterbukaan inilah yang dibutuhkan oleh guru agar mempunyai modal dasar dalam menyikapi keberagaman budaya peserta didik.

Sehubungan dengan itu, dipahami oleh guru PAI bahwa masyarakat adalah kunci dalam menyadarkan multikulturalisme seorang guru. Ketertutupan terhadap kebudayaan seseorang biasanya datang dari kompetensi guru yang enggan melihat perbedaan. Guru terlihat kaku dan tertutup pada kebudayaan lain. Ia enggan melihat alternatif ragam kebudayaan yang ada. Namun sikap eksklusivisme tersebut akan terkikis

\footnotetext{
${ }^{22}$ Nur Jamilah, Wawancara (Mojokerto 6 Juni 2019)

${ }^{23}$ Abdul Rohman, Wawancara (Mojokerto 08 April 2019)

${ }^{24}$ Observasi SMP Negeri 1 Mojosari tanggal 08 Agustus 2019
} 
mana kala, seorang guru mempunyai kompetensi sosial, di mana ia mampu membaur dengan masyarakat multikultural.

5. Kompetensi leadership.

Kompetensi leadership adalah kemampuan guru yang mampu menjadi pemimpin dalam kelasnya. Keberadaan guru dalam mengajar dan membimbing peserta didik seharusnya mempunyai kompetensi pribadi berupa kemampuan menjadi imam bagi peserta didiknya. Ia tegas namun tidak otoriter, demokratis bukan apatis. Layaknya seorang imam, guru yang mempunyai leadership sangat dibutuhkan oleh peserta didik, mengingat dirinya mampu menjelma sebagai orang yang dapat mengarahkan siswa atau peserta didik dalam konteks multikultural. ${ }^{25}$

Sehubungan dengan itu pula, kompetensi keilmuan, multikultural, sosial, profesional dan leadership tersebut, tidak menafikan kompetensikompetensi guru secara umum seperti pedagogi, sosial, kepribadian dan profesionalisme. Secara umum kompetensi tersebut melekat pada profesi guru sebagai tenaga pengajar. Namun karena konteks yang dibangun adalah nilai-nilai multikultural kompetensi seperti keilmuan, multikultural, profesional, sosial dan leadership perlu juga direnungkan kembali dalam mencapai tujuan multikultural.

\section{Klasifikasi Ruang Lingkup Kompetensi Multikultural}

Temuan penelitian tentang kompetensi multikultural Guru Pendidikan Agama Islam sebagai instrumen dalam memandang sejauh mana guru Pendidikan Agama Islam dapat dikatakan multikulturalis, dapat diukur dengan kompetensi multikultural sebagaimana berikut: pertama kompetensi keilmuan. Kompetensi keilmuan yang dimaksud adalah penguasaan guru terhadap khazanah dan wawasan tentang multikulturalisme. Serta kajian agama Islam yang komprehensif dan progresif. Kedua kompetensi multikultural adalah kemampuan guru dalam bersikap kepada peserta didik yang berbeda kebudayaan seperti toleransi dan tidak diskriminatif. Ketiga kompetensi profesional adalah kemampuan profesionalisme guru yang termanifestasikan pada kesadaran guru untuk bertindak multikultural sebagaimana tuntutan profesinya. Keempat kompetensi sosial yaitu kecakapan guru dalam menempatkan dirinya pada masyarakat multikultural. Kelima kompetensi leadership adalah kapabilitas guru dalam aspek kepemimpinan dan manajerial yang diimplementasikan pada ranah pembelajaran dan pengajaran.

Secara teoretis Ilghiz memberikan gambaran tentang kompetensi yang dibutuhkan oleh guru multikultural. Pertama adalah untuk menjadi guru multikultural dibutuhkan sikap positif dalam konteks keragaman

${ }^{25}$ Nur Jamilah, Wawancara (Mojokerto 6 Juni 2019) 
budaya. Pendidik yang bertugas pada lingkungan multikultural harus memiliki sikap positif dan toleran terhadap nilai, budaya dan norma dari murid yang berlatar belakang kebudayaan berbeda. Kedua guru multikultural diharapkan mampu untuk menguasai pengetahuan tentang nilai-nilai etnis nasional dan global, keberagaman aneka budaya serta pembawaan khusus peserta didik yang dipengaruhi oleh sosial-budaya maupun nilai-nilai agama; serta tradisi pedagogis yang berasal dari beragam budaya yang ada pada ruang kelas. Ketiga pedagogi skill di mana guru multikultural dengan skill pengajarannya seperti manajemen kelas serta pengorganisasian pelajaran mampu menjadikan peserta didik mengembangkan sikap positif, toleran terhadap keanekaragaman budaya ${ }^{26}$ Berikut ini akan diuraikan masing-masing ruang lingkup kompetensi multikultural sebagaimana disebut:

\section{Sikap Positif Guru PAI}

Sikap positif terhadap keberagaman. Ilghiz memaknainya dengan sikap konstruktif guru PAI untuk mendukung kebijakan dan gerakan sekolah dalam membangun pendidikan multikultural serta meningkatkan wawasan tentang pemahaman multikultural dan pengetahuan global. Jika berangkat dari kompetensi multikultural guru PAI sebagaimana dimaksud, jelas sikap positif guru PAI yang berusaha meningkatkan kapasitasnya sebagai guru PAI terlihat pada sub-bab tentang bagaimana ikhtiar guru pendidikan agama Islam dalam meningkatkan wawasan multikulturalnya. Di sisi lain sikap positif guru pendidikan agama Islam dalam mendukung gerakan sekolah terhadap pendidikan multikultural meskipun hal itu tidak tampak secara eksplisit, tetapi kesadaran dan kepekaan akan arti pentingnya pendidikan multikultural selalu didukung oleh guru PAI.

Sikap positif yang paling tampak dari guru PAI terhadap pentingnya pendidikan multikultural di sekolah adalah bukti dukungan para guru dalam mengimplementasikan tujuan pembelajaran Kompetensi Inti (KI) 2 dalam pengajarannya. ${ }^{27}$ Searah dengan pengetahuan umum tentang Kompetensi Inti (KI) dalam struktur kurikulum nasional bangsa Indonesia yang mengklasifikasikan kompetensi inti menjadi 4 bagian. Kompetensi Inti (KI) 1 yang dideskripsikan sebagai sikap spiritual seperti beriman dan ketakwaan kepada Tuhan Yang Maha Esa, KI 2 sebagai sikap sosial seperti berakhlak mulia, mandiri, sehat, gotong royong, toleransi dan demokratis, KI 3 sebagai

${ }^{26}$ Ilghiz M Sinagatullin, Costructing Multicultural Education in a Divers Society (London: Scarecrow, 2003) hlm 237

${ }^{27}$ Abdul Rohman, Wawancara (Mojokerto 08 April 2019) 
kompetensi yang berhubungan dengan pengetahuan dan KI 4 yang diterjemahkan dengan keterampilan. ${ }^{28}$

Uraian tersebut menunjukkan bagaimana sikap positif guru Pendidikan agama Islam ditunjukkan lewat dukungannya dalam mengimplementasikan KI 2 yang sarat dengan nilai-nilai multikultural. Dalam arti lain bahwa sikap positif tersebut dapat dilihat pada kompetensi multikultural guru yang diartikan dengan kepekaan terhadap keberagaman peserta didik dan penghargaan serta penghormatan guru terhadap keanekaragaman budaya dan perbedaan menjadi sesuatu yang menunjang sikap positif guru sebagai prasyarat menjadi guru multikultural. Begitu juga kompetensi sosial seperti ramah, toleran dan sikap menghargai perbedaan tanpa tebang pilih

2. Penguasaan Khazanah Multikulturalisme

Pengetahuan tentang ragam kebudayaan dan nilai-nilainya sebagai kompetensi multikultural guru, pada konteks penelitian ini terwujud pada sikap guru PAI dalam memperdalam pengetahuan dan khazanah kajian Islam. Khazanah keislaman dan penguasaannya terhadap teks agama menjadi kompetensi utama guru Pendidikan Agama Islam, tidak lain karena profesionalisme guru PAI bertumpu pada penguasaan terhadap teks-teks keagamaan. Namun yang dibutuhkan dari penguasaan teks agama tidak lain untuk dapat memberikan perimbangan terhadap perbedaan-perbedaan dan cara pandang memahami teks agama.

Tidak jarang bahwa dalam satu kelas, kendati yang dihadapi oleh guru Pendidikan Agama Islam adalah peserta didik muslim, namun keberagaman pemikiran dan praktik beribadah pun dapat berbeda antara satu murid dengan lainnya. Contohnya adalah bagaimana seorang guru PAI menghadapi peserta didik yang berbeda mazhab fikihnya. Guru PAI multikultural membutuhkan kompetensi terhadap penguasaan konteks perbedaan cara pandang dan praktik ibadah yang berbeda dari peserta didik. Harus diakui bahwa perbedaan ulama' dalam mengkaji dan berijtihad terhadap teks-teks agama tidak terlepas dari faktor paradigma berpikir ulama', serta setting kebudayaan di mana kajian agama itu muncul. Oleh karena itu idealnya guru PAI multikultural mempunyai pandangan fikih multikulturalisme sebagai basis pengajarannya. Fikih multikulturalisme berupaya untuk menyadarkan pada guru bahwa perbedaan dalam hal furuiyah adalah hal yang wajar dan tidak perlu dibesar-besarkan. Oleh karena paradigma berpikir serta kondisi sosio-historis ulama' berbeda-beda

28 Andi Prastowo, Menyusun Rencana Pelaksanaan Pembelajaran (RPP) Tematik Terpadu: Implementasi Kurikulum 2013 untuk SD/MI (Jakarta: Kencana, 2017) hlm 120 
antara satu dengan lainnya. Pada akhirnya setting sosial ini dapat menyebabkan perbedaan ijtihad di antara ulama'. ${ }^{29}$ Oleh karena itu kedalaman dan progresivitas pengetahuan kajian agama menjadi penting dalam basis pengetahuan guru PAI multikultural.

3. Skill Pedagogi Guru

Basis skill pedagogi adalah kompetensi guru yang berkaitan dengan keterampilan guru dalam mengembangkan multikulturalisme pada peserta didik. Skill pedagogi lebih diartikan pada kecakapan guru dalam mengelola dan mengembangkan pembelajaran multikultural. Sehubungan dengan itu, kompetensi yang masuk pada ranah ini adalah kompetensi profesional guru dan kompetensi pedagogi guru Pendidikan Agama Islam. Selaras dengan apa yang digambarkan oleh informan yang menyatakan bahwa kompetensi guru multikultural Pendidikan agama Islam adalah kompetensi profesional. Terjemahan kompetensi profesional dalam pandangan guru PAI adalah sejauh mana kesadaran guru pendidikan agama Islam menyadari profesinya untuk tujuan menghadapi peserta didik multikultural.

Dalam konteks skill pedagogi guru pendidikan agama Islam yang relevan dengan terjemahan Illghiz, peneliti melihat cakupan skill pedagogi sebagai bagian dalam kompetensi guru PAI multikultural dapat dilihat sejauh mana strategi dan implementasi pembelajaran multikultural. Skill pedagogi guru terlihat jelas pada kompetensi profesional guru. Pengertian lainnya adalah kompetensi profesional guru dalam konteks pendidikan di Indonesia dalam menjalankan amanah profesionalisme guru mengantarkan pada sikap positif dalam mendukung gerakan yang mendukung pengembangan nilai-nilai multikultural. selain itu sikap positif guru dalam mengembangkan pendidikan multikultural dalam konteks penelitian ini didukung dengan kompetensi sosial dan kompetensi multikultural guru. Pengertian ini dapat dijabarkan dengan skill pedagogi guru dalam mengimplementasikan pembelajaran multikultural pada aspek content, media pembelajaran, strategi dan metode pembelajaran. Meskipun dalam hal ini Senyampang pengamatan peneliti tentang skill pedagogi guru PAI dalam mengimplementasikan multikulturalisme masih terkesan normatif dan prosedural.

4. Kompetensi Leadership

Temuan penelitian tentang kompetensi leadership sebagai bagian dalam mengembangkan multikulturalisme guru PAI ini berbeda dan unik dari apa yang diterjemahkan oleh Ilghiz. Kompetensi ini menurut pandangan guru PAI adalah kemampuan yang seharusnya melekat pada guru

29 Tobroni, Memperbincangkan Pemikiran Pendidikan Islam: dari Idealisme Substantif hingga Konsep Aktua (Jakarta: Kencana, 2018) hlm 248 
Pendidikan Agama Islam. Kompetensi leadership memberikan makna bagaimana seorang guru mampu mengelola pembelajaran Pendidikan Agama Islam. Mengelola dan memanaje pembelajaran PAI dapat dipahami dengan bagaimana cara guru PAI merencanakan, mengorganisasikan, memimpin dan mengawasi pembelajaran.

Kompetensi leadership guru merupakan kapabilitas guru dalam mempengaruhi peserta didik sehingga tindakan dan sikap dapat terarah sesuai dengan tujuan ideal guru dalam membimbing peserta didik. Lebih lanjut kompetensi leadership ini dapat pula diterapkan oleh guru dengan menerapkan gaya kepemimpinan transformasional yaitu:

a. Guru adalah gambaran ideal di mana ia mampu menjadi teladan, dihormati, dipercaya dan dapat mengambil keputusan dalam meningkatkan hasil kualitas pembelajaran

b. Guru dapat memberikan motivasi kepada peserta didik atau rekannya agar dapat memiliki tanggung jawab dan komitmen terhadap tujuan sekolah dalam mengembangkan pendidikan

c. Guru mampu memberikan sumbangsih berupa pemikiran kritis, solutif dan inovatif agar dapat menumbuhkan kreativitas sekolah dalam mengembangkan pembelajaran ke arah yang lebih baik

d. Guru dapat menjadi sosok pembimbing dan trainer serta menyajikan umpan balik yang baik bagi siswa dan rekan sejawatnya. ${ }^{30}$

Aplikasi kompetensi leadership sebagaimana pernyataan di atas jika dihubungkan dengan konteks dan data penelitian dapat dipahami bahwa guru PAI dengan kompetensi kepemimpinannya mampu menjadi teladan sikap multikultural bagi peserta didik. Selanjutnya guru mampu memberikan motivasi dalam rangka menguatkan nilai-nilai multikultural bagi peserta didiknya, mampu menjadi penasihat dan pembimbing peserta didik mengembangkan nilai-nilai multikultural dan memberikan sumbangan positif agar pendidikan multikultural dapat berkembang dengan baik di lingkungan sekolah.

Dalam pada itu, peneliti menyimpulkan kompetensi multikultural guru PAI sebagaimana disebutkan oleh Ilghiz dapat dimengerti dengan mengambil temuan-temuan penelitian seperti kompetensi pengetahuan, sosial, multikultural, profesional. Dalam aspek basis pengetahuan multikultural guru PAI dituntut untuk mempunyai kepekaan dan wawasan yang cukup tentang multikulturalisme dan teks kajian agama. Sedangkan sikap positif guru PAI multikultural termanifestasikan pada kompetensi

${ }^{30}$ Hamid Darmadi, Pengantar Pendidikan Era Globalisasi: Konsep Dasar, Teori, Strategi dan Implementasi Pendidikan Globalisasi (Jakarta: An1mage, 2019) hlm 76 
sosial, multikultural dan profesional. Terakhir tentang kompetensi leadership dapat diterjemahkan dengan kemampuan guru dalam memimpin dan mengembangkan pendidikan multikultural. Berikut ini adalah tabel penjelasan kompetensi multikultural guru PAI

Tabel: Kompetensi Multikultural Guru PAI

\begin{tabular}{|c|c|c|c|}
\hline Sikap Positif & $\begin{array}{l}\text { Basis } \\
\text { Pengetahuan } \\
\text { Multikultural }\end{array}$ & $\begin{array}{c}\text { Skill } \\
\text { Pedagogi } \\
\text { Multikultural }\end{array}$ & $\begin{array}{l}\text { Kompetensi } \\
\text { Leadership }\end{array}$ \\
\hline $\begin{aligned} \text { a. Kompetensi } \\
\text { sosial } \\
\text { b. Kompetensi } \\
\text { multikultural }\end{aligned}$ & $\begin{array}{l}\text { a. Penguasaan } \\
\text { terhadap teks- } \\
\text { teks agama } \\
\text { b. Penguasaan } \\
\text { terhadap kajian } \\
\text { multikultural }\end{array}$ & $\begin{array}{l}\text { Kompetensi } \\
\text { profesional }\end{array}$ & $\begin{array}{l}\text { Kepemimpinan } \\
\text { Guru dalam } \\
\text { mengembangkan } \\
\text { pendidikan } \\
\text { multikultural }\end{array}$ \\
\hline
\end{tabular}

\section{KESIMPULAN}

Kajian kompetensi multikultural guru Pendidikan Agama Islam yang mengambil lokus Musyawarah Guru Mata Pelajaran Pendidikan Agama Islam kabupaten Mojokerto berdasar pada urgensi kompetensi multikultural guru PAI dalam konteks pendidikan di Indonesia. Jamak diketahui bahwa Indonesia sebagai negara Majemuk membutuhkan pendidik yang sadar terhadap keragaman dan kemajemukan budaya bangsa Indonesia. Tujuannya agar proses pendidikan dapat menghargai dan selaras dengan nilai-nilai kebudayaan bangsa Indonesia. Terlebih lagi bagi guru PAI yang berusaha menginternalisasikan nilai-nilai agama pada peserta didik. Internalisasi nilai dan pengembangan agama Islam bagi siswa diharapkan dapat sejalan dan mengapresiasi keragaman kultural bangsa.

Sehubungan dengan itu, hasil penelitian tentang kompetensi multikultural yang dibutuhkan oleh guru Pendidikan Agama Islam dalam konteks keragaman budaya peserta didik di antaranya adalah: kompetensi keilmuan yang diartikan dengan kemampuan guru dalam memahami keberagaman budaya peserta didik, masyarakat baik dalam tataran regional, nasional ataupun global. Selain itu kompetensi keilmuan tersebut juga dapat diartikan sebagai penguasaan materi keislaman guru secara progresif yang mampu menjawab dilema-dilema perbedaan keragaman budaya peserta didik; Kompetensi multikultural yakni sikap guru PAI yang mampu memberikan contoh sikap multikultural seperti menghormati dan menghargai perbedaan; Kompetensi profesional adalah kemampuan guru dalam merefleksikan jabatan dan profesinya untuk melihat keragaman kultur siswa yang diajarnya; Kompetensi sosial adalah kemampuan guru dalam menempatkan diri di tengah-tengah masyarakat multikultural; Kompetensi 
leadership adalah keberdayaan guru sebagai pemimpin di kelas ataupun di lingkungannya untuk mengarahkan dan mengembangkan nilai-nilai multikultural pada peserta didik.

Sedangkan dalam klasifikasi ruang lingkupnya kompetensi multikultural guru PAI dapat dikategorikan sebagai berikut: pertama bahwa guru PAI diharapkan mempunyai sikap positif terhadap latar multikultural peserta didik, di mana guru mampu mengaplikasikan kompetensi sosial dan kompetensi multikulturalnya pada lingkungannya. Kedua guru PAI disyaratkan memiliki basis pengetahuan multikultural yang memadai. Ruang lingkup tersebut dapat dipahami dengan kemampuan guru menguasai kajian multikultural dan kompetensi materi keislaman yang progresif. Ketiga skill pedagogi guru, yang bermakna bahwa refleksi dan kesadaran guru terhadap profesinya dapat mengembangkan multikulturalisme dan nilai-nilainya pada peserta didik. Keempat ruang lingkup kepemimpinan guru dalam menyemaikan dan mengembangkan pendidikan multikultural pada peserta didik.

\section{DAFTAR PUSTAKA}

A Z, Mulyana. 2010. Rahasia Menjadi Guru Hebat. Jakarta: Grasindo Bakri, Masykuri. 2013. Metode Penelitian Kualitatif Tinjauan Teoretis dan Praktis Malang: Unisma Press.

Cresswel, Jhon W. 2014. Research Design: Pendekatan Kualitatif, Kuantitatif dan Mixed Yogyakarta: Pustaka Pelajar.

Darmadi, Hamid. 2019. Pengantar Pendidikan Era Globalisasi: Konsep Dasar, Teori, Strategi dan Implementasi Pendidikan Globalisasi. Jakarta: An1mage

Harto, Kasinyo. 2014. Model Pengembangan Pedidikan Agama Islam. Jakarta: Raja Grafindo

Muhaimin. 2016. Model Pengembangan Kurikulum dan Pembelajaran dalam Pendidikan Islam Kontemporer. Malang: UIN Maliki Press

Prastowo, Andi. 2017. Menyusun Rencana Pelaksanaan Pembelajaran (RPP) Tematik Terpadu: Implementasi Kurikulum 2013 untuk SD/MI. Jakarta: Kencana

Raihani. 2016. Pendidikan Islam dalam Masyarakat Multikultural. Yogyakarta: Pustaka Pelajar

Rofaah. 2017. Pentingnya Kompetensi Guru dalam Kegiatan Pembelajaran Perspektif Islam. Yogyakarta: Depublish

Setiawan, Conny R. 2010. Metode Penelitian Kualitatif: Jenis, Karakteristik dan Keunggulannya Jakarta: Grasindo

Sinagatullin, Ilghiz M. 2003. Constructing Multicultural Education in a Diversity Society. USA: Scarecrow Press 
Smith, Jonathan A. 2009. Interpretative Phenomenological Analysis: Theory, Methode and Research, Los Angeles; Sage

Syamsul Bachri. 2017. Psikologi Pendidikan Berbasis Analisis Empiris Aplikatif. Jakarta: Prenada Media Thalib,

Tim Pengembang Ilmu Pendidikan UPI. 2007. Ilmu dan Aplikasi Pendidikan bag 4. Jakarta: Grasindo

Tobroni. 2018. Memperbincangkan Pemikiran Pendidikan Islam: dari Idealisme Substantif hingga Konsep Aktual Jakarta: Kencana.

http://sumberdaya.ristekdikti.go.id/wp-content/uploads/2016/02/uu-nomor14-tahun-2005-ttg-guru-dan-dosen.pdf ,. 2007.Undang-undang nomor 20 Tahun 2003 tentang Sistem Pendidikan Nasional Jakarta: Visimedia,

Ghony, Djunaidi. 2016. Desain Pengembangan Kurikulum Pendidikan Agama Islam Multikultural. Malang: Unisma

Parekh, Bhiku. 2012. Rethinking Multiculturalism terj: Rethinking Multiculturalism: Keberagaman Budaya dan Teori Politik Yogyakarta: Kanisius.

Hasan, Muhammad Tolchah. 2016. Pendidikan Multikultural Sebagai Opsi Penanggulangan Radikalisme Malang: Unisma. 